\title{
PATRIA PIETAS - CONDIȚIA JURIDICĂ A COPILULUI ÎN FAMILIA POSTMODERNĂ
}

DOI: $\quad 10.24193$ /SUBBiur.65(2020).4.8

\section{Emese FLORIAN*}

Rezumat: Din motive evidente, copilul are nevoie de ocrotire și este beneficiar al ocrotirii, a părinților pe cât este posibil; pe de altă parte, el este titularul arsenalului de drepturi și libertăți ale copilului consacrate prin documente internaționale și reflectate în legislația noastră internă.

Drepturile și îndatoririle părintești privitoare la persoana și la bunurile copilului, desemnate generic prin sintagma „autoritate părintească” sunt impregnate de drepturile copilului (I) și circumstanțiază exercițiul amintitei autorități (II). părintești.

Cuvinte cheie: copil, minor, autoritate părintească, exercițiul autorității

* Prof..univ.dr., Facultatea de Drept, Universitatea „Babeş-Bolyai” Cluj-Napoca. contact:

florian.emese23@gmail.com. 


\title{
PATRIA PIETAS - THE LEGAL CONDITION OF THE CHILD IN THE POSTMODERN
}

FAMILY

\begin{abstract}
For obvious reasons, the child requires protection and is beneficiary of said protection, usually received by his/her parents; on the other hand, he/she possesses wide array of children's rights and freedoms stipulated in international documents and reflected in our domestic law.

Parental rights and duties regarding the person and the child's property, generically designated by the phrase "parental authority", are impregnated by the rights of the child (I) and circumscribe the exercise of that authority (II).
\end{abstract}

Keywords: child, parental authority, exercise of parental authority

\section{Cuprins}

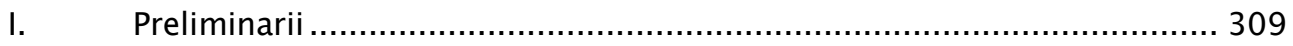

II. Autoritatea părintească și drepturile copilului .................................... 313

III. Exercitarea autorității părintești și drepturile copilului ........................... 321

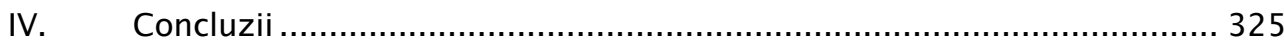




\section{Preliminarii}

Familia este, s-a spus, o construcție juridică, culturală, sociologică având propria structură, propria organigramă. ${ }^{1}$

Ierarhia famailială riguroasă promovată secole la rând după exemplul roman care îl învestea pe pater cu patria potestas, e de domeniul trecutului în locul modelulului patriarhal s-a instalat paradigma exercitării în comun a autorității părintești, adică, prin definiție, o distribuție egalitară a „puterilor” între cei doi părinți. Fie că sunt căsătoriți, divorțați ori din afara căsătoriei, tatăl și mama sunt, fiecare, titular al autorității părintești și regula cere să exercite autoritatea împreună cu celălalt părinte, fiindcă este maniera care dă satisfacție principiului suprem al interesului copilului.

Legislația noastră civilă - avem în vedere cu precădere dispozițiile relative familiei - întrebuințează termenul „copil” alternativ cu acela de „minor”, afară de cazul în care subiectul de drept cu pricina este desemnat, prețios, prin „copil minor” (e.g, art. 400, 437 alin. (2), 493, 497 alin. (1) C.civ.).

În context familial „copilul”, inserat în texte normative cu semnificaţia din vorbirea curentă, este unul și același cu juridica sa clonă, „minorul” în expresie ordinară, adică persoana care nu a împlinit vârsta de 18 ani și, pe cale de consecință, ca regulă, nu are capacitate deplină de exercițiu (art. 38 C.civ.). De pildă, în sensul prevederilor vizând protecția copilului, el este descris

${ }^{1}$ D. Alland, S. Rials, Dictionnaire de la culture juridique, PUF, 2014, p. 698.

${ }^{2}$ Despotismul lui pater familias, având ius vitae necisque (drept de viață și de moarte) asupra alor săi este legendar. Ar fi cu totul greșit să conchidem că în dreptul roman nu au existat evoluții în direcția limitării puterilor capului de familie; unele dintre acestea, retrospectiv și din unghiul supușilor amintitei puteri, ar putea fi consemnate ca având natură protectivă. Cu privire la puterea părintească în diferitele epoci ale dreptului roman, a se vedea V. Hanga, Drept privat roman, Editura Didactică și Pedagocică, București, 1977, p. 187-190. 
astfel: „persoana care nu a împlinit vârsta de 18 ani și nici nu a dobândit capacitate deplină de exercițiu, în condițiile legii” [art. 263 alin. (5) C.civ., art. 4 lit. a) din Legea nr. 272/2004 privind protecţia și promovarea drepturilor copilului, republicată $\left.{ }^{3}\right]$. În consecință, drepturile și îndatoririle părintești se exercită „până la data când copilul dobândește capcitate deplină de exercițiu” (art. 484 C.civ.). ${ }^{4}$ Meritul noțiunii de „minor” este precizia sa aritmetică. Factorul discernământ, cu un rol cheie în logica incapacității, nu are a face cu matematica.

Termenul „copil”, cu trimitere la „descendent”, are darul de a evoca relația de familie grație căreia și în mijlocul căreia persoana a ocupat locul său unic în șirul generațional.

Se pare că a pătruns în textele de lege în contextul mișcărilor internaționale de promovare a drepturilor copilului creionate, într-o primă etapă, ${ }^{5}$ ca versiune, o transpunere a drepturilor omului, ale adultului: s-a

3 M. Of. nr. 159 din 5 martie 2014.

4 Interesantă este inițiativa în sprijinul recunoașterii unei categorii juridice intermediare între starea de minor şi starea de major, anume starea de tânăr - ceva între copilul trecut și proaspătul adult - pornindu-se de la observația că trecerea brutală de la o stare juridică la alta nu ține seama în măsura recomandată de alte științe sociale de factorul maturizare progresivă a adolescentului. A se vedea D. Guérin, Entre protection et autonomie, AJ Famille, nr. 5/2020, p. 272.

Ideea nu este cu totul nouă. În 2014, de asemenea în Franța, s-a propus renunțarea la principiul incapacitâții minorului în favoarea conceptului de „capacitate prospectivă” ce s-ar dobândi la vârsta de 13 ani şi ar aduce cu sine prezumția irefragabilă de discernământ; pe cale de consecință, de la 13 ani, manifestarea de voință a copilului ar deveni obligatorie. A se vedea Ph. Malaurie, H. Fulchiron, Droit de la famille, 6e éd., LGDJ, 2017, p. 717, nota nr. 14.

5 Nevoia protejării copilului neajutorat într-o lume a adulților a prins contur în a doua jumătate a secolului XIX. Printre primele reglementări cu asemenea ambiții, apătute în Franța, sunt meționate Legea din 7 decembrie 1874 cu privire la protejarea copiilor aangajaţi în munci ambulante, Legea din 24 iulie 1889 privtor la protecţia copiilor maltrataţi și abandonați - Ph. Malaurie, H. Fulchiron, op. cit., p. 709. 
considerat inadecvată asocierea drepturilor fundamentale cu persoanajul „minor”, pentru că vocabula, în iremediabilă antinomie cu „majorul”, plasasează instinctiv subiectul „infantil” într-o poziție de inferioaritate, de inaptitudine în exerciţiul unora şi aceloraşi drepturi. ${ }^{6}$ Instrumentele internaţionale consacrate copilului nu sunt interesate de situația juridică a copilului, ci de drepturile sale. Optica e semnificativ diferită față de aceea de „minor” din abordările legii civile, fiindcă preocuparea nu este aceea de a descrie o suită de reguli aplicabile copilului, ci de a indica drepturile ce-i sunt recunoscute în calitatea sa de subiect, de persoană înzestrată cu libertate. Schimbarea de viziune este asemnănătoare aceleia care a marcat trecerea de la „condiția juridică a femeii” la „drepturile femeii”, cu deosebirea, esențială, că în cazul copilului este inaplicabilă rețeta decretării egalității în drepturi cu toți ceilalții indivizi; copilul nu este o persoană oarecare, de aceea o legislație anume dedicată este indispensabilă. Aceste evoluții au revelat, de asemenea, nevoia inversiunii de perspectivă: situaţia copilului este de evaluat din

Primul document internațional preocupat de condiția copilului este Declarația de la Geneva privind Drepturile Copilului adoptată de Liga Națiunilor Unite în 1924. Elaborat de fondatoarea mișcării Save the Children, Eglantyne Jebb, Declarația a avut doar un rol orientativ pentru statele membre. Punctul de referință în materie îl reprezintă Convenția ONU cu privire la drepturile copilului, adoptată la 29 noiembrie 1989 (ratificată de România prin Legea nr. 18/1990, M. Of. nr. 109 din 28 septembrie 1990), care a marcat trecerea de la „copilul - obiect al protecției” la copilul „subiect de drepturi”. Potrivit definiției cuprinse în art. 1 din Convenție, „prin copil se înțelege orice fiinţă umană (!, s.n.) sub vârsta de 18 ani, exceptând cazurile în care legea aplicabilă copilului stabileşte limita majoratului sub această vârstă”.

${ }^{6} \mathrm{Ph}$. Malaurie, Droit des personnes. La protection des mineurs et des majeurs, $10^{\mathrm{e}}$ éd., LGDJ, 2018, p. 291. 
punctul de vedere al copilului însuși, al interesului său superior, ${ }^{7}$ opozabil inclusiv părinților. ${ }^{8}$

Fără îndoială, consacrarea internațională a drepturilor copilului are merite de necontestat - cum ar fi recunoașterea copilului şi a copilăriei prin ceea ce este iar nu ca imagine a sa în negativ, la fel și universalitatea drepturilor sale.

Bunele intenții sunt însă punctate de unele scăderi: învestind copilul cu drepturi ale omului (adult), nu i se răpeşte oare tocmai copilăria? drepturile sunt recunoscute „copilului” oricare ar fi vârsta sa, ceea ce e nefiresc şi neverosimil de vreme ce o bună perioadă din copilărie se prezumă lipsa discernământului, a voinței conștiente; interesul superior al copilului, deopotrivă rațiunea, condiția, finalitatea oricărei măsuri privitoare la copil, indiferent de autorul ei, este, în cele din urmă apreciat ca atare de către decidentul adult iar nu de către însuşi copil. ${ }^{9}$

\footnotetext{
7 Formula însăşi de „interes superior al copilului” invită la reflecţie. În ce sens este „superior” interesul copilului? E de interpretat ca interes de perspectivă al copilului, prioritar față de cel de moment? de supremație față de eventualul interes incomplet pliat al părintelui/părinților? În fine, „interesul superior al copilului”, prin invitația la superprotecția acestuia, nu contrazice oare ideea de autonomie a copilului care animă Convenția ONU privind drepturile copilului? Pentru unele dezvoltări a se vedea J,. Carbonnier, Droit civil, vol. I., PUF, 2004, p. 829. În ce ne privește, nu excludem cu totul ca la origini să se afle un exces de conformitate literală a traducerii din limba engleză a expresiei „best interest of child” din Convenția ONU cu privire la drepturile copilului. În aceeași manieră, „everyones's best interest” s-ar traduce ca „interes superior al fiecăruia".

8 În același sens, O. Ghiță, S. Cercel, Interesul superior al copilului, în RRDP nr. 3/2018, p. 135-136.

S-a remarcat, cu ironie, că „via noțiunea de inters superior al copilului mai toate instituţiile dreptului familial riscă să devină superflue" - J. Carbonnier, apud. Ph. Malaurie, H. Fulchiron, op. cit., p. 711, nota nr. 42. Ghilimele dismulează orice simpatie față de franchețea concluziei. 9 Ph. Malaurie, H. Fulchiron, op.cit., p. 712.
} 
Așadar, pe de o parte, copilul, din motive evidente, are nevoie şi este beneficiarul ocrotirii, a părinților pe cât este posibil, pe de altă parte este titularul arsenalului de drepturi și libertăţi ale copilului. Drepturile şi îndatoririle părintești desemnate generic prin sintagma „autoritate părintească” sunt impregnate de drepturile copilului (II) și circumstanțiază exercițiul amintitei autorități (III).

\section{Autoritatea părintească și drepturile copilului}

Termenul „autoritate” din compunerea expresiei „autoritate părintească" ${ }^{\prime 10}$ provine din latinescul auctoritas, având o încărcătură semnantică duală: de putere a subiectului însuşi, inerentă lui şi de notorietate pentru ceilalți - ceea ce, în epoca noastră, ar putea avea corespundent în putere de persuasiune - dar, de asemenea, înțelesul de putere ca potestas, de superioritate/dominație în relația cu altcineva, putere exercitată asupra unui subiect - altfel spus, în limbaj modern, puterea de a impune propria voință. ${ }^{11}$

Sintagma „autoritate părintească” este succesoarea „ocrotirii părinteşti” din reglementarea Codului familiei, a cărei substanță o conservă.

10 S-a afirmat că abandonarea noțiunii de „putere părintească” în favoarea noțiunii de „autoritate părintească” în legislațiile europene s-a făcut pentru a se realiza desprinderea de viziunea arhaică a familiei bazată pe puterea lui pater familias din vechiul drept roman asupra copiilor, asimilați cu sclavii și bunurile, ceea ce evoca lipsa totală a personalității juridice a copiilor pe toată durata vieții tatălui - M. Avram, Drept civil. Familia, ed. a 2-a, Ed. Hamangiu, 2016, p. 485 nota nr. 1.

Într-un remarcabil studiu, autoarea definește autoritatea ca prerogativă a titularului/purtă torului său de a exprima în relația cu subiectul autorității și în interesul acestuia din urmă o superioritate epistemică și/sau o superio ritate deontică. M. Avram, Nimeni nu vine la Tatăl decât prin Mine: o incursiune în logica autorității și a puterii în dreptul privat, RRDP nr. 2/2019, www.Lege5.ro (1 septembrie 2019).

${ }^{11}$ D. Alland, S. Rials, op.cit., p. 111. 
Şi una şi cealaltă conferă atribute de supraveghere, de control şi de decizie exercitate cu privire la copil, în interesul superior al copilului. Rolul autorității părintești este de acela de pază a copilului vulnerabil din pricina fragilității sale fizice/psihice/emoționale; menirea instituției de suplinire a incapacității minorului ca actor pe scena juridică, incapacitate ce face necesar recursul la instituția reprezentării/asistării, a alunecat pe un plan secund.

Sub denumirea marginală „conținutul autorității părintești”, art. 487 C.civ. dispune: „părinţii au dreptul și îndatorirea de a crește copilul, îngrijind de sănătatea și dezvoltarea lui fizică, psihică şi intelectuală, de educația, învățătura şi pregătirea profesională a acestuia, potrivit propriilor lor convingeri, însuşirilor şi nevoilor copilului; ei sunt datori să dea copilului orientarea şi sfaturile necesare exercitării corespunzătoare a drepturilor pe care legea le recunoaște acestuia”. ${ }^{12}$

Pornind de la norma cadru tocmai evocată și ținând seama de prevederile care o detaliază în segmentul interesând persoana copilului, art. 488-499 C.civ., în literatură s-a încetățenit formula de „drepturi şi îndatoriri” părintești în îndeplinirea misiunii de creștere a copilului.

O primă constatare: propriu-zis, suntem în prezența unui pachet de îndatoriri/obligații părintești sau, într-o altă exprimare, a unui complex de prerogative, ${ }^{13}$ fără vreun drept părintesc opozabil copilului - cum ar fi, să spunem, obligația copilului de a avea locuința aleasă de părinții săi. ${ }^{14}$ Este de la sine înțeles, părinții sunt cei care stabilesc locuința copilului - rezultă din

\footnotetext{
12 Un reputat autor are următorul comentariu pe marginea prevederii cvasiidentice a legii franceze: „bla, bla, bla” - Ph. Malaurie, op.cit., p. 292..

$13 \mathrm{Ph}$. Malaurie, H. Fulchiron, op.cit., p. 705.

14 Potrivit art. 371-3 C.civ.fr., „L'enfant ne peut, sans permission des père et mère, quitter la maison familiale et il ne peut en être retiré que dans les cas de nécessité que détermine la loi.”.
} 
cele dispuse de art. 496 C.civ. - însă tonul imperativ din enunțul „copilul minor locuiește la părinții săi” [art. 496 alin. (1) C.civ.] nu are corespondent în obligația copilului de a respecta decizia părinților. În schimb copilul, dacă a împlinit vârsta de 14 ani, poate cere părinților schimbarea locuinței sale în vederea desăvârşirii învățăturii sau pregătirii sale profesionale, iar în caz de împortivire, copilul se poate adresa instanței de tutelă (art. 498 C.civ.).

Locuința copilului „leagă” mai curând părinții copilului între dânşii decât copilul și părinții săi. Astfel, dacă părinții sunt căsătoriți dar nu locuiesc împreună, locuința soțului la care se află copilul dobândește, prin simplul fapt că implicit este şi căminul copilului, statut de „locuință a familiei” [art. 321 alin. (1) C.civ.] și prin aceasta intră sub incidența unui regim juridic specific, oricare ar fi regimul matrimonial al soților și indiferent de titlul sub care este deținut imobilul (art. 322 C.civ.). În caz de divorț, consecințele stabilirii locuinței copilului la unul dintre părinți unită cu exercitarea în comun a autorități părintești poate avea urmări bizare: schimbarea locuinței copilului împreună cu părintele cu care locuiește, dacă afectează exercițiul drepturilor părintești sau al unor drepturi părintești, nu poate avea loc decât cu acordul prealabil al celuilalt părinte [art. 497 alin. (1) C.civ.]. Aceasta însemnă că în cazul recăsătorii părintelui „rezident”, dacă schimbarea de stare civilă aduce cu sine și schimbarea locuinței sale, îndatorirea de a locui împreună cu soțul său din căsătoria subsecventă aşa cum prevede legea [art. 309 alin. (2) C.civ.], se poate lovi de împotrivirea fostului soț, în calitate de părinte.

Apoi, enumerarea cuprinsă în art. 487 C.civ. amintește mai degrabă de găselnița aviatorului din povestea Miculului Prinț a lui Saint-Exupéry desenăm o cutie și pretindem că oaia este înăuntru - decât de rigoarea unei dispoziții a legii. Drept urmare, lista drepturilor şi îndatoririlor părintești este formula consacrată - ce dau consistență „autorității părintești” diferă de 
autor la autor. ${ }^{15} \mathrm{La}$ o analiză atentă, chiar unele din sarcinile unanim incluse în conținutul autorității părintești sunt susceptibile de amendare. Avem în vedere obligația legală de întreținere față de copil, căci „tatăl și mama sunt obligați, în solidar, să dea întreținere copilului lor minor, asigurându-i cele necesare traiului, precum şi educația, învățătura şi pregătirea sa profesională”

15 Identificarea respectivelor drepturi și îndatoriri diferă de la autor la autor. Astfel, într-o părere, sub titlul „drepturi și obligații părintești privitoare la persoana copilului”, părinții au dreptul și obligația de a stabili și păstra identitatea copilului, de a crește copilul, de a avea legături personale cu copilul, de a veghea la creșterea, educarea, învățătura și pregătirea profesională a acestuia, dreptul de a stabili locuința copilului, dreptul de a consimți la căsătoria, logodna și adopția copilului, precum și dreptul de a contesta măsurile dispuse de autorități cu privire la copil și de a formula cereri și acțiuni în nume propriu și în numele copilului (M. Avram, Drept civil. Familia, op.cit., p. 488- 499). Într-o sistematizare apropiată, sunt identificate dreptul și îndatorirea părinților de a crește copilul îngrijind de sănătatea, dezvoltarea, educația, învățătura și pregătirea profesională a acestuia, dreptul de a stabili locuința copilului, de a cere înapoierea copilului de la orice persoană care îl ține fără drept, dreptul de a avea legături personale cu copilul, de a consimți la logodna, căsătoria, adopția copilului, dreptul părinților de a-și exprima opinia cu privire la emanciparea copilului, dreptul și îndatorirea de a întreține copilul, de a reprezenta sau, după caz, de a încuviința actele minorului (D. Lupaşcu, C.M. Crăciunescu, Dreptul familiei, ed. a 3-a emendată și actualizată, Ed. Universul Juridic, București, 2018, p. 545-554);

În doctrina anterioară noului Cod civil, s-a afirmat că îndatoririle principale ale părinților sunt acelea de a creşte şi de a întreține copilul, pentru a căror îndeplinire legea a instituit dreptul părinților de a stabili locuința copilului, precum şi dreptul de a cere înapoierea acestuia de la orice persoană l-ar ține fără drept (I. Albu, Dreptul familiei, Editura Didactică și pedagogică, București, 1975, p. 327); într-o altă exprimare, părinților le revin următoarele drepturi şi obligații privitoare la persoana copilului: dreptul şi îndatorirea de a creşte copilul, dreptul de a lua anumite măsuri față de copil, dreptul de a cere înapoierea copilului de la orice persoană care îl ține fără drept, dreptul de a consimți la adopția copilului, dreptul de a avea legături personale cu acesta, dreptul de a veghea la creşterea, educarea, învățătura şi pregătirea profesională a copilului, dreptul de a stabili locuința copilului (I.P. Filipescu, A.I. Filipescu, Tratat de dreptul familiei, ed. a 8-a, revăzută și adăugită, Ed. Universul Juridic, București, 2006, p. 636-647).

Potrivit doctrinei franceze, autoritatea părintească „înzestrează” cu următoarele drepturi și îndatoriri: de a stabili locuința copilului, de a supraveghea copilul, dreptul și îndatorirea ambilor părinți de a se îngriji de educația copilului, precum și de sănătatea acestuia, dreptul și îndatorirea de a-l asocia pe minor în toate deciziile care îl privesc [A. Gouttenoire, Autorité parentale, în P. Murat (coord.), Droit de la famille, 8éd., Dalloz, 2019, p. 972-980).

\section{6}


[art. 499 alin. (1) C.civ.]. Să observăm că obligația părintească cu pricina de asemenea există față de descendentul devenit major aflat în continuarea studiilor [art. 499 alin. (3) C.civ.], cu toate că în privința beneficiarului părinții nu mai au a exercita drepturi și îndatoriri părintești (art. 484 C.civ.). Posibila obiecţie, în sensul că, în cazul întreținerii datorate de părinţi copilului conținutul obligației este unul complex, implicând, alături de furnizarea celor trebuincioase traiului, asigurarea mijloacelor necesare educației, învățăturii și pregătirii profesionale, prin urmare este firească încorporarea sa în conceptul cadru „autoritate părintească”, nu credem că poate fi reținută. Același raționament susține starea de nevoie a creditorului descendent major. În fond, nevoile copilului, la fel şi nevoile descendentului major aflat în continuarea studiilor sunt dictate, în parte, de cheltuielile cu educația, învăţătura, pregătirea profesională și argumentează cuantumul întreținerii datorate, de drept comun, potrivit cu nevoia celui care o cere şi cu mijloacele celui care urmează a o plăti [art. 529 alin. (1) C.civ.]. Prin urmare, obligația de înțreținere apre ca expresie a solidarităţii intrafamiliale, oricare ar fi persoanele dintre cele limitativ enumerate de lege între care se leagă in conreto.

În fine, tatăl și mama au dreptul și îndatorirea de a îndruma copilul îngrijindu-se de educaţia, învățătura, pregătirea sa profesională, de dezvoltarea sa intelectuală, spirituală, morală și socială, potrivit propriilor convingeri, precum și însușirilor și nevoilor copilului; părinții sunt datori să ofere copilului orientarea şi sfaturile necesare exercitării corespunzătoare a drepturilor recunoscute lui - mai spune legea în art. 487 C.civ. În consecință, părinții copilului sunt îndrituiți să aleagă felul educației care urmează să fie dată copilului lor și, de asemenea, au obligația să înscrie copilul la școală și să asigure frecventarea cu regularitate a cursurilor școlare [art. 51 alin. (1) și (2) din Legea 
nr. 272/2004, republicată]. Împlinind 14 ani, minorul are drept de inițiativă în legătură cu educația sa școlară, el poate cere părinților să își schimbe felul învățăturii sau al pregătirii profesionale ori locuința necesară desăvârșirii învăţăturii ori pregătirii profesionale, iar dacă părinții se opun, se poate adresa instanței de tutelă care va hotărî, cu ascultarea copilului, pe baza raportului de anchetă psiho-socială (art. 498 C.civ.).

În sensul cel mai larg, „educația” copilului înseamnă, afară de instruirea școlară, de pregătirea profesională, și educația sa religioasă, morală, civică, într-un cuvânt toate acele influențe care modelează și pregătesc minorul pentru viața de adult.

Cât privește educația religioasă a copilului, părinții sunt cei care îndrumă minorul, potrivit propriilor convingeri, în alegerea unei religii, în condițiile legii, ținând seama de opinia, vârsta și de gradul de maturitate al acestuia, fără a-l putea obliga să adere la o anumită religie sau la un anumit cult religios [art. 491 alin. (1) C.civ.]. Libertatea părinților de a alege religia copilului este de asemenea consacrată de art. 14 alin. (2) din Convenția ONU cu privire la drepturile copilului, prin care statele părți s-au angajat să respecte drepturile şi obligațiile părinților sau, după caz, ale reprezentanţilor legali ai copilului de a-l îndruma în exercitarea dreptului la libertate de gândire, de conştiință şi religie, de o manieră care să corespundă capacităţilor în formare ale acestuia.

În această materie, dreptul de îndrumare este recunoscut exclusiv părinților, nu și altui reprezentant legal al minorului; când minorul beneficiază de protecţie specială - plasament, plasament în regim de urgență - persoanelor în îngrijirea cărora se află le sunt interzise orice acțiuni menite să influențeze convingerile religioase ale copilului [art. 30 alin. (4) din Legea 
nr. 272/2004, republicată]. Copilul care a împlinit 14 ani îşi poate alege liber confesiunea religioasă [art. 491 alin. (2) C.civ.] ${ }^{16}$.

Știm cu toții, în viața reală îndrumarea copilului nu se poate realiza numai pe calea colaborării, uneori este nevoie de „recuzita părintească” mai fermă care să influențeze în sensul dorit sau să corijeze comportamentul copilului în familie şi în afara ei. Legiuitorul nu exclude ideea de corecție a copilului, dar cere ca măsurile disciplinare să fie luate de părinți cu respectarea demnității copilului și interzice luarea unor măsuri, precum și aplicarea unor pedepse fizice, de natură a afecta dezvoltarea fizică, psihică sau starea emoțională a copilului (art. 489 C.civ.). În acelaşi sens, potrivit Legii nr. 272/2004, sunt interzise pedepsele corporale sub orice formă, la fel și orice alte tratamente umilitoare sau degradante ori privarea copilului de drepturile sale, de natură să pună în pericol viața, dezvoltarea fizică, mentală, spirituală, morală sau socială, integritatea corporală, sănătatea fizică sau psihică, atât în familie, cât şi în orice instituție care asigură protecția, îngrijirea sau educarea copiilor (art. 33, art. 95). În îndeplinirea misiunii lor, părinții sunt invitați să coopereze cu copilul [art. 488 alin. (2) lit. a) C.civ.] și să-l asocieze la toate deciziile care îl privesc, ținând seama de vârsta și de gradul său de maturitate [art. 483 alin. (2) C.civ.]. Este limpede, ideea de autoritate este ruinată de vreme ce cooperarea cu copilul, asocierea sa în luarea deciziilor implică o relație de egalitate între părinți și copil, relație prin definiție incompatibilă cu potestas-ul uneia dintre părți asupra alteia.

Enunțat prin art. 493 C.civ., dreptul şi îndatorirea părinţilor de a supraveghea copilul este atribut al autorității părintești inseparabil dreptului

\footnotetext{
16 Observăm lipsa de „sincronizare” a prevederilor art. 491 alin. (2) C.civ. cu cele statuate prin art. 30 alin. (3) din Legea nr. 272/2004, republicată, potrivit cărora copilul își poate alege singur religia de la 16 ani împliniți.
} 
şi îndatoririi generale de a creşte copilul şi conferă părinților controlul asupra preocupărilor și asupra anturajului copilului. Îndatorirea părinților de a supraveghea copilul explică răspunderea instituită în sarcina acestora pentru fapta prejudiciabilă a minorului. Răspunderea civilă delictuală a tatălui și a mamei este o răspundere principală, directă, autonomă și obiectivă; vinovăţia sau nevinovăţia minorului autor al prejudiciului nu are nicio relevanță în ceea ce privește nașterea obligației părinților de reparare a prejudiciului ${ }^{17}$.

Atributul supravegherii nu are caracter absolut și nu poate fi exercitat discreționar, ci numai în interesul superior al copilului. Părinții sunt obligați să respecte viața intimă, privată, precum și demnitatea copilului ${ }^{18}$ [art. 16 alin. (1) şi (2) din Convenția ONU cu privire la drepturile copilului, art. 22 din Legea nr. 272/2004, republicată, art. 488 alin. (2) lit. a) C.civ.] și sunt îndrituiți să împiedice corespondența sau relațiile personale numai în cazul copilului în vârstă de până la 14 ani şi doar pe baza unor motive temeinice (art. 494 C.civ.), de unde lesne se deduce că asemenea interdicții nu pot fi impuse copilului care a împlinit 14 ani.

Legat de posibilitatea ca părinții să cenzureze relațiile „sociale” ale copilului, cum pe bună dreptate s-a remarcat, din interpretarea coroborată a prevederilor art. 494 C.civ. cu dispoziții cuprinse în Legea nr. 272/2004, republicată [îndeosebi art. 17 alin. (1) și (2)] reiese că vizate sunt relațiile sau legăturile de familie ale copilului, precum cele existente între copil și bunicii

\footnotetext{
17 Pe larg, L. Pop, I. F. Popa, S.I. Vida, Curs de drept civil. Obligațiile, Ed. Universul Juridic, București, 2015, p. 365-366.

18 Despre „demnitatea” ființei umane în general, fie copil, fie adult, s-a spus că este o noțiune generică imposibil de definit, iar „aventura” sa juridică nu este lipsită de pericole, deoarece imprecizia ce o caracterizează riscă să abandoneze drepturi civile în voia unor judecăți personale inpirate de convingeri morale adesea şovăielnice. O. Ungureanu, C. Munteanu, Dreptul la demnitate în concepția Codului civil, RRDP, nr. 1/2016, p. 37.
}

\section{0}


săi, sau frații și surorile sale, ori care decurg dintr-o relație de familie de facto. Interdicția nu se extinde și asupra persoanelor din afara cercului celor cărora legea le recunoaște dreptul de a avea relații personale și contacte directe cu minorul, prin urmare părinții pot limita orice alte legături și relații pe care le consideră a avea influență nefastă asupra copilului, indiferent de vârsta lui. Altminteri, fără acest corectiv, s-ar aduce o gravă atingere însuși conţinutului autorităţii părintești - se afirmă în doctrină ${ }^{19}$.

\section{Exercitarea autorității părintești și drepturile copilului}

În consecința calității de cotitulari ai autorității, precum și a faptului că ambii părinți răspund pentru creșterea copilului lor minor [art. 483 alin. (1) și (3) C.civ.], tatăl și mama exercită împreună și în mod egal drepturile părintești și îndeplinesc tot astfel îndatoririle ce le revin [art. 503 alin. (1) C.civ.]. Este regula instituită de Codul civil, o regulă fondată pe raportul de filiație, prin urmare imună la circumstanțieri date de statusul relațiilor dintre părinți - dacă sunt căsătoriți sau nu, dacă aceștia conviețuiesc sau nu. În esență, coparentatea instaurată a eliminat decalajul din reglementarea anterioară dintre calitatea de titular de drepturi și îndatoriri părintești a fiecăruia dintre părinți, pe de o parte și puterea de a exercita/îndeplini drepturile, respectiv îndatoririle părintești, pe de altă parte. Relația dintre a deține autoritatea părintească și a exercita autoritatea părintească este asemănătoare aceleia dintre capacitatea de folosință și capacitatea de exercițiu a persoanei fizice: calitatea de părinte conferă, prin

19 În acest sens, C. Irimia, Comentariul art. 494, în Fl.A. Baias, E. Chelaru, R. Constantinovici, I. Macovei (coord.), Noul Cod civil. Comentariu pe articole, ed. a 2-a, Ed. CH Beck, București, 2014, p. 592-593, nr. 2-7. 
ea însăşi, drepturile și îndatoririle părintești, adică o „capacitate de folosință” ce nu se pierde, nu poate face obiectul renunțării, însă dinamica, punerea în valoare a prerogativelor din portofoliul parental, „capacitatea de exercițiu”, presupune condiții și condiționalități (e.g., exercitarea autorităţii părintești sau exercitarea unor drepturi părintești poate fi retrasă cu titlu de sancțiune în condițiile art. 508 C.civ.). Inovația legii este aceea că a generalizat „capacitatea de exercițiu” a autorității părintești oricare ar fi statutul părinților şi indiferent dacă aceștia conviețuiesc ori nu.

Dintr-un alt unghi, relația dintre fiecare dintre părinţi şi copil nu are a face cu natura sau calitatea relației dintre cei doi părinți, sunt planuri cvasitotal distincte.

Fără să ne arogăm expertiză pe care nu o deținem altfel decât prin experiență de viață, o atare separație a celor două planuri nu credem că are vreo semnificație câtă vreme relațiile dintre părinți sunt normale - recurgând la o formulă uzitată în vorbirea curentă; în schimb supralicitează calităţile personale ale fiecăruia dintre părinții aflați într-o relație conflictuală, cum se înțâmplă, adesea, în cazul foștilor soți. Cum anume se traduce în fapt exercițiul comun al autorității părintești de către părinţii care au decis să-și continue viața unul fără celălalt? Cât este de realistă această regulă clădită pe mitul cuplului parental care supraviețuiește triumfător vicisitudinilor de orice fel, inclusiv eșecului vieții de cuplu, totul în interesul superior al copilului?

În primele zile de aplicare a Codului civil din 2009, în contextul divorțului părinților, o instanță a decis că tatăl copiilor, separat de aceștia, în numele principiului exercitării în comun a autorității părintești este îndrituit să-i viziteze zilnic, câte 3 ore pe zi, la locuința mamei. ${ }^{20}$

20 Jud. Oradea, sent. civ. nr. 9546 din 3 octombrie 2011 (www.rolii.ro). 
De bună seamă, dozajul cantitativ al timpului petrecut de către fiecare dintre părinți alături de copil nu poate fi nici condiția, nici finalitatea și nici semnul calitativ distinctiv al exercitării în comun a autorității părintești. Este de la sine înțeles că în majoritatea covârșitoare a cazurilor relațiile dintre părinți și copii nu vor avea parametri din timpul căsătoriei sau, după caz, al conviețuirii părinților. Teoretic, prerogativele părintești sunt egale şi au același conținut ca și în timpul căsătoriei/conviețuirii; practic, prin forța împrejurărilor, prezența și rolul unuia dintre părinți în viața copilului devine preponderent.

Cât privește luarea deciziior, spre a preveni consecințe nedorite ale exercitării „bicefale” a autorității părintești, legea prevede că, față de terții de bună-credință, oricare dintre părinți îndeplinind singur un act curent pentru este prezumat că are și consimțământul celuilalt părinte [art. 503 alin. (2) C.civ.]. În alte cuvinte, se prezumă mandatul tacit reciproc între părinți pentru actele curente săvârşite în exercitarea drepturilor și îndeplinirea îndatoririlor părintești. Per a contrario, actele importante referitoare de copil fac necesar acordul expres al tatălui și al mamei. Problema e, fie că vorbim de părinți, fie de instanța de tutelă chemată să arbitreze diferendul dintre părinți, calificarea unui act anume ca fiind din categoria celor uzuale sau, dimpotrivă, a celor semnificative. Legiuitorul a revenit $\mathrm{cu}$ indicații: sunt importante decizii precum cele referitoare la alegerea felului învățăturii sau pregătirii profesionale, tratamente medicale complexe sau intervenții chirurgicale, reședința copilului sau administrarea bunurilor [art. 36 alin. (3) din Legea nr. 272/2004, republicată, dispoziție introdusă prin Legea nr. 257/2013²1]. La

\footnotetext{
${ }^{21}$ Legea nr. 257/2013 pentru modificarea și completarea Legii nr.272/2004 privind protecția și promovarea drepturilor copilului a fost publicată în M.Of. nr. 607 din 30 septembrie 2013.
} 
scurtă vreme, legea drepturilor copilului a fost din nou supusă modificării ${ }^{22}$, fiind introdusă o prevedere - devenită art. 36 alin. (4) - care, din punctul nostru de vedere, a marcat neechivoc un pas în retragere față de ceea ce începuse să prindă contur ca înțeles al exercitării în comun a autorității părinteşti: în situația în care, din orice motiv, un părinte nu îşi exprimă voinţa pentru luarea deciziilor importante, acestea se iau de către părintele cu care copilul locuiește, cu excepția situației în care acest lucru contravine interesului superior al copilului.

În aceeaşi tendință de repliere față de efectivitatea exercițiului comun al autorității părintești, până la modificarea sa prin Legea nr. 169/2016 $6^{23}$, Legea privind regimul liberei circulații a cetățenilor români în străinătate, nr. $248 / 2005^{24}$, condiționa călătoria copilului aflat sub exercițiul comun al autorității părintești dar însoțit doar de unul dintre părinți de dovada acordului celuilalt exprimat în formă autentică notarială şi cuprinzând o serie de mențiuni riguros detaliate (destinaţia, perioada călătoriei, scopul deplasării, ruta urmată etc.); în actuala alcătuire a textului, consimțământul părintelui care nu îl însoțește pe copil este unul generic, pentru deplasări în străinătate neprecizate, și poate acoperi o perioadă semnificativă, de 3 ani [art. 30 alin. (1) lit.d)]. ${ }^{25}$

\footnotetext{
22 Legea nr. 272/2004 privind protecția și promovarea drepturilor copilului, în forma republicată (M. Of. nr. 159 din 5 martie 2014).

23 Legea 169/2016 pentru modificarea și completarea Legii nr. 248/2005 privind regimul liberei circulații a cetățenilor români în străinătate a fost publicată în M. Of. nr. 772 din 3 octombrie 2016.

24 Publicată în M.Of. nr. 682 din 29 iulie 2005.

25 Pentru o analiză detaliată se poate vedea C. M. Crăciunescu, O măsură în interesul copiilor?, Universul Juridic, www.Lege5.ro, nr. 8/2017 (o9 august 2017).
} 
Nevoia de adaptare a exercițiului comun al autorităţii părintești la situația concretă a relațiilor dintre părinți este o certitudine jurisprudențial confirmată în cazul emiterii unui ordin de protecție faţă de unul dintre părinți în condițiile Legii nr. 217/2003 pentru prevenirea și combaterea violenței domestice, republicată. ${ }^{26}$. În baza dispoziţiilor actului normativ invocat, instanța de tutelă poate dispune, printre altele, interzicerea oricărui contact, inclusiv telefonic, prin corespondență sau în orice alt mod, cu victima [art. 23 alin. (1) lit. f)]. Or, când unul dintre părinţi are blocate toate canalele de comunicare cu celălalt pentru o perioadă anume - stabilită de judecător, făă a se putea depăşi 6 luni de la data emiterii ordinului, art. 24. alin. (1) - prin forța împrejurărilor „devălmășia” exercițiului autorității părintești este așezată între paranteze. Problema e exprimarea juridică a parantezei. S-a avansat soluția, împărtășită de noi, a exercitării autorității părintești de către un singur părinte (de regulă părintele victimă, care locuiește împreună cu copilul), temporar, pe durata măsurii de protecție, în temeiul prevederilor art. 507 C.civ. potrivit cărora unul dintre părinți preia integral sarcinile parentale, printre altele, în cazul în care celălalt părinte se află, din orice motiv, în imposibilitatea de a-și manifesta voința. ${ }^{27}$

\section{Concluzii}

Alăturate, două dispoziții legale având același obiect de reglementare, edictate în momente istorice diferite, sunt grăitoare pentru (r)evoluția condiției copilului în mediul său natural, familia: art. 329 C. civ. din 1864,

\footnotetext{
${ }^{26}$ M. Of. nr. 205 din 24 martie 2014.

27 C.M. Crrăciunescu, Exercițiul autorităţii părintești în condițiile existenței unui ordin de protecție, Universul Juridic, www.Lege5.ro., nr. 5/2016 (12 mai 2016).
} 
„Tatăl care va avea motive de nemulțumire foarte grave asupra purtărei copilului său va avea următoarele mijloace de îndreptare”, respectiv art. 483 alin. (2) C.civ. din 2009, „Părinții exercită autoritatea părintească numai în interesul superior al copilului, cu respectul datorat persoanei acestuia, și îl asociază pe copil la toate deciziile care îl privesc”. Schimbarea de paradigmă juridică e completă: odinioară aflat sub puterea tatălui, copilul este centrul de gravitație al relațiilor de familie, iar părinții săi, amândoi, au îndatorirea de a crește copilul în condiții care să asigure dezvoltarea sa fizică, mentală, spirituală, morală și socială în mod armonios.

Familia a devenit o construcție pedocentrică. Vocația, temporară, a autorităţii părintești este în slujba interesului superior al copilului. Patria pietas. 